Pemanfaatan Jurnal Online Perpustakaan BPTP Yogyakarta Dwi Titaningsih, Suharno

Kerja Sama antara SDM Perpustakaan untuk Menuju Layanan Prima dan Unggul Endang Fatmawati

Revitalisasi Peran Perpustakaan Umum bagi Masyarakat Noorika Retno Widuri

Optimalisasi Layanan Penelusuran Sumber-sumber Informasi untuk Mendukung Penulisan Karya Ilmiah Dosen dan Mahasiswa di Perguruan Tinggi Dian Hapsari

Memperkuat Peran Pustakawan dalam Mewujudkan Layanan Perpustakaan Perguruan Tinggi yang Prima dan Unggul Bambang Hermanto

Aktivitas Mahasiswa dalam Membaca Skripsi di Perpustakaan Masriyatun

Budaya Peduli dan Budaya Mutu Melayani di Perpustakaan SMP Negeri 13 Surakarta Menuju Sekolah Menyenangkan Ria Widyawati

Redesain Website UPT Perpustakaan Universitas Sebelas Maret sebagai Media Pendidikan Pengguna bagi Pemustaka Tri Hardian Satiawardana

Peran Perpustakaan dalam Membangun Citra Perpustakaan di Era Teknologi Informasi Sri Anawati

Komunitas Pustakawan Menulis (upaya menyebarluaskan dan melestarikan pengetahuan) Tri Hardiningtyas 


\section{Jurnal}

\section{Pustaka Ilmiah}

\section{Jurnal Ilmiah UPT Perpustakaan UNS}

Jurnal Pustaka Ilmiah (JPI) sebagai media kreasi para pustakawan, guru, dosen, dan praktisi dalam pengembangan profesi secara berkelanjutan. Berbagai ide dan gagasan kreatif menjadi bahan kajian yang diimplementasikan dalam berbagai model pengembangan bahan pustaka, baik cetak maupun online. Kreativitas menjadi akar pengembangan ilmu pengetahuan sepanjang hayat dengan berbagai model pengembangan budaya literasi di perpustakaan. Keindahan dan kecermatan dalam sebuah tulisan ilmiah dan nonilmiah akan dapat direalisasikan secara nyata oleh sumber daya manusia untuk menghasilkan SDM yang unggul dan kreatif dengan membaca dan menulis untuk menyinari dunia. Budaya literasi menjadi upaya untuk pengembangan dan pemberdayaan perpustakaan sebagai pusat sumber belajar untuk mendukung tri dharma perguruan tinggi.

\section{SUSUNAN REDAKSI}

Penanggung Jawab

Ketua Redaksi

Wakil Redaksi

Sekretaris

Penyunting Ahli

Penyunting

Bendahara

Sirkulasi
: Dr. Muhammad Rohmadi, M.Hum.

: Dra. Tri Hardiningtyas, M.Si.

: Haryanto, M.IP.

: Bambang Hermanto, S.Pd., M.IP., Henny Perwitosari, A.Md.

: 1. Dr. Muhammad Rohmadi, M.Hum. (Universitas Sebelas Maret);

2. Drs. Widodo, M.Soc.Sc. (Universitas Sebelas Maret);

3. Drs. Harmawan, M.Lib. (Universitas Sebelas Maret).

: Daryono, S.Sos., M.IP.; RiahWiratningsih, S.S., M.Si., Dinar Puspita Dewi, S.Sos., M.IP.; Sri Utari, S.E.

: Nurul H., A. Md.; Novi Tri Astuti, A.Md.

: Aji Hartono, A. Md.; Agus Sriyono, A.Md.; Aris Suprihadi, S.IP.

UPT PERPUSTAKAAN UNS

REDAKSI JURNAL PUSTAKA ILMIAH

Alamat: Jl. Ir. Sutami 36A Kentingan, Surakarta 57126

Telp./Fax.: (0271) 654311; email: jurnal.pustaka.ilmiah@gmail.com 


\section{Pengantar Redaksi}

\section{Salam Pustaka.}

Dengan mengucap rasa syukur kepada Allah SWT. segenap Tim Redaksi Jurnal Pustaka Ilmiah (JPI) mengucapkan banyak terima kasih kepada para penulis yang telah berkontribusi untuk penerbitan JPI volume 2 edisi Juni 2016. Penerbitan volume 2 kali ini JPI mengetengahkan tema: Pengembangan Perpustakaan menuju Layanan Prima dan Unggul. Kehadiran JPI diharapkan dapat dijadikan sebagai media penulisan bagi para pustakawan, dosen, tenaga kependidikan, guru, dan praktisi untuk menuangkan ide dan gagasan kreatifnya secara tertulis.

Dalam penerbitan JPI volume 2 bulan Juni 2016 ini disajikan sepuluh tulisan antara lain: (1) Pemanfaatan Jurnal Online Perpustakaan BPTP Yogyakarta (Dwi Titaningsih dan Suharno), (2) Kerja Sama Antara Sumber Daya Manusia Perpustakaan untuk Menuju Layanan Prima dan Unggul (Endang Fatmawati), (3) Revitalisasi Peran Perpustakaan Umum Bagi Masyarakat (Noorika Retno Widuri), (4) Optimalisasi Layanan Penelusuran Sumber-Sumber Informasi untuk Mendukung Penulisan Karya Ilmiah Dosen dan Mahasiswa di Perguruan Tinggi (Dian Hapsari), (5) Memperkuat Peran Pustakawan dalam Mewujudkan Layanan Perpustakaan Perguruan Tinggi yang Prima dan Unggul (Bambang Hemanto), (6) Aktivitas Mahasiswa dalam Membaca Skripsi di Perpustakaan FISIP-UNS (Masriyatun), (7) Budaya Peduli dan Budaya Mutu Melayani di Perpustakaan SMP Negeri 13 Surakarta Menuju Sekolah Menyenangkan (Ria Widyawati), (8) Redesain Website UPT Perpustakaan Universitas Sebelas Maret Surakarta sebagai Media Pendidikan Pengguna Bagi Pemustaka (Tri Hardian Satiawardana), (9) Peran Perpustakaan dalam Membangun Citra Perpustakaan di Era Teknologi Informasi (Sri Anawati), (10) Komunitas Pustakawan Menulis : upaya menyebarluaskan dan melestarikan pengetahuan (Tri Hardiningtyas).

Akhirnya, redaksi JPI mengucapkan banyak terima kasih kepada Kepala UPT Perpustakaan UNS yang telah memberikan dukungan dan memfasilitasi untuk penerbitan JPI. Selain itu, ucapan terima kasih juga disampaikan kepada para penulis, tim redaksi, dan Yuma Pressindo, yang telah mempersiapkan dari awal sampai terbitnya JPI. Selamat membaca.

Surakarta, Juni 2016

Ketua Redaksi 


\section{Sambutan}

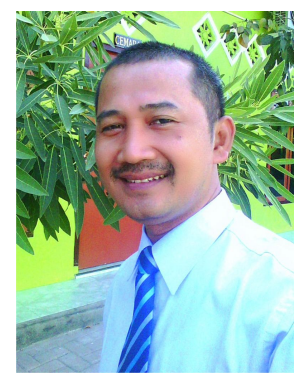

Dr. Muhammad Rohmadi, M.Hum.

\section{Kepala UPT Perpustakaan UNS}

Selamat dan sukses atas diterbitkannya kembali Jurnal Pustaka Ilmiah (JPI). Jurnal ini sebagai media kreativitas dan pengembangan softs skills para pustakawan, guru, dosen, dan praktisi untuk menuangkan ide dan gagasan demi layanan perpustakaan yang prima dan unggul. Berbagai isu terkait dengan pengembangan perpustakaan, pelayanan perpustakaan sebagai pusat sumber belajar, pendidikan, penelitian, pelestarian, dan budaya literasi akan menjadi topik-topik yang disajikan dalam jurnal ilmiah ini.

Diterbitkannya JPI sebagai bukti kepedulian UPT Perpustakaan Universitas Sebelas Maret Surakarta (UNS) dalam rangka turut berpartisipasi mengembangkan dan membudayakan literasi untuk para pustakawan dan civitas akademika di UNS maupun luar UNS. Berbagai model pengembangan softs skills menjadi alternatif untuk membekali dan memperkuat jaringan kerja sama penulisan antar kelembagaan. Dengan demikian, kerja sama antar pustakawan dan pemustaka dapat diwujudkan dengan berbagai model dalam bidang literasi.

Penerbitan JPI merupakan sarana untuk memotivasi semua pustakawan agar berkarya di bidang penulisan, baik ilmiah maupun nonilmiah. Para pustakawan harus menjadi pionir dalam bidang penulisan. Hal ini sebagai bentuk kepedulian dan keteladaan para pustakawan yang memproses, menyajikan, dan menikmati bahan-bahan pustaka cetak dan noncetak di perpustakaan. Ketersedian bahan pustaka akan menjadi bahan paling nyata untuk dikembangkan dalam berbagai model perwujudan teknik penulisan. Hal terpenting yang harus dimiliki oleh para pustakawan adalah semangat untuk berbagi pengetahuan melalui tulisan.

Kepedulian setiap sumber daya manusia kepada kelembagaan dapat dituangkan dalam berbagai model pengabdian, salah satunya adalah melalui tulisan. Berbagai ide dan gagasan dapat direalisasikan dengan berbagai model bentuk artikel jurnal, buku, modul, monograf, dan lain sebagainya. Para civitas akademika, guru, praktisi harus memiliki keterampilan menulis sebagai bentuk perwujudan pengembangan diri secara berkelanjutan. Berbagai tulisan dan referensi sudah disajikan tetapi masih sangat minim untuk diimplementasikan dalam kehidupan. Banyak orang pandai dalam berbicara tetapi masih sedikit yang menuangkan ide dan gagasannya dalam bentuk tulisan.

Akhirnya, keluarga besar UPT Perpustakaan UNS mengucapkan banyak terima kasih kepada Rektor, Wakil Rektor, pengelola JPI, penulis, dan semua pihak yang telah mendukung penerbitan JPI. Semoga dengan diterbitkannya JPI ini dapat menjadi media untuk menulis para pustakawan, dosen, guru, dan praktisi dalam bidang iptek dan seni. Ucapan terima kasih juga diucapkan kepada percetakan Yuma Pressindo yang telah membantu mempersiapkan dari awal sampai terbitnya JPI ini. Akhirnya, semoga JPI dapat memberikan nilai kemaslahatan untuk umat. 


\section{DAFTAR ISI}

\section{JURNAL PUSTAKA ILMIAH EDISI KEDUA: VOLUME 1 NOMOR 2/ JUNI 2016}

\section{Tema: Pengembangan Perpustakaan Menuju Layanan Prima dan Unggul}

Pemanfaatan Jurnal Online Perpustakaan BPTP Yogyakarta

Dwi Titaningsih, Suharno

Kerja Sama antara SDM Perpustakaan untuk Menuju Layanan Prima dan Unggul

Endang Fatmawati

Revitalisasi Peran Perpustakaan Umum bagi Masyarakat.

Noorika Retno Widuri

Optimalisasi Layanan Penelusuran Sumber-sumber Informasi untuk Mendukung Penulisan Karya Ilmiah Dosen dan Mahasiswa di Perguruan Tinggi..

Dian Hapsari

Memperkuat Peran Pustakawan dalam Mewujudkan Layanan Perpustakaan Perguruan Tinggi yang Prima dan Unggul.

Bambang Hermanto

Aktivitas Mahasiswa dalam Membaca Skripsi di Perpustakaan

Masriyatun

Budaya Peduli dan Budaya Mutu Melayani di Perpustakaan SMP Negeri 13 SurakartaMenuju SekolahMenyenangkan.

Ria Widyawati

Redesain Website UPT Perpustakaan Universitas Sebelas Maret sebagai Media Pendidikan Pengguna bagi Pemustaka.

Tri Hardian Satiawardana

Peran Perpustakaan dalam Membangun Citra Perpustakaan di Era Teknologi Informasi

Sri Anawati

Komunitas Pustakawan Menulis (upaya menyebarluaskan dan melestarikan pengetahuan)

Tri Hardiningtyas 


\title{
OPTIMALISASI LAYANAN PENELUSURAN SUMBER-SUMBER INFORMASI UNTUK MENDUKUNG PENULISAN KARYA ILMIAH DOSEN DAN MAHASISWA DI PERGURUAN TINGGI
}

\author{
Dian Hapsari \\ Pustakawan Universitas Sebelas Maret Surakarta \\ Email: dianhapsariku@gmail.com
}

\begin{abstract}
Publication of scientific papers for lecturers and students is a demand that can not be avoided. In order to find information as an ingredient in the manufacture of scientific work, the necessary sources of quality information and reliable. The library, in this case the librarian must be responsive and observant in seeing user needs. One way that can be done by librarians in providing information relating to the publication of scientific works of faculty and students is by providing search services information sources. To be able to do it optimally, it needs the capability to master the sources of information, including how to use search facilities and information search strategy. Thus, the term college library as the heart really can be realized with the maximum.
\end{abstract}

Keywords: information search, librarians, scientific papers

\begin{abstract}
ABSTRAK
Publikasi karya ilmiah bagi kalangan dosen dan mahasiswa merupakan tuntutan yang tidak dapat dihindari. Agar dapat menemukan informasi sebagai bahan dalam pembuatan karya ilmiah, diperlukan sumber-sumber informasi yang berkualitas dan terpercaya. Perpustakaan, dalam hal ini pustakawan harus tanggap dan jeli dalam melihat kebutuhan pemustaka. Salah satu cara yang dapat dilakukan oleh pustakawan dalam menyediakan informasi yang berkaitan dengan publikasi karya ilmiah dosen dan mahasiswa adalah dengan memberikan bantuan layanan penelusuran sumbersumber informasi. Agar dapat melakukannya secara optimal, diperlukan kemampuan penguasaan sumber-sumber informasi, termasuk di dalamya cara menggunakan fasilitas penelusuran dan strategi penelusuran informasi. Dengan demikian, istilah perpustakaan sebagai jantung perguruan tinggi benar-benar dapat terwujud dengan maksimal.
\end{abstract}

Kata kunci: penelusuran informasi, pustakawan, karya ilmiah

\section{PENDAHULUAN}

Kewajiban untuk publikasi karya ilmiah bagi kalangan perguruan tinggi, yakni dosen dan mahasiswa, merupakan tuntutan yang tidak dapat dihindari. Bagi dosen, selain sebagai salah satu syarat wajib untuk meningkatkan jenjang karier, menulis karya ilmiah juga merupakan salah satu syarat untuk mendapatkan hibah-hibah penelitian. Sementara itu, bagi mahasiswa, berdasarkan surat edaran Dirjen
Dikti nomor 152/E/T/012 tentang publikasi karya ilmiah, menulis karya ilmiah merupakan salah satu syarat kelulusan bagi mahasiswa jenjang sarjana, magister, dan doktor.

Hal tersebut masih ditambah lagi dengan gaung "World Class University", di mana salah satu tolok ukur yang digunakan sebagai dasar pemeringkatan adalah karya ilmiah yang dihasilkan oleh para civitas akademika yang dapat diakses melalui feature Google Scholar. 
Agar dapat menulis kemudian menerbitkan karya ilmiah tersebut, tentu ada tahapantahapan yang harus dilakukan. Proses tersebut dimulai dari membuat permasalahan, memilih sumber-sumber informasi, melakukan analisis dan evaluasi data, dan menyajikan hasil karya ilmiah, yang kesemuanya bukanlah hal yang mudah bagi yang belum terbiasa. Proboyekti (2015) menyebutkan beberapa permasalahan yang dihadapi oleh dosen dan mahasiswa dalam proses penulisan sebuah karya ilmiah. Kesulitan yang dihadapi oleh mahasiswa dalam proses penulisan karya ilmiah, antara lain kurangnya kemampuan:

a. memahami tugas yang diberikan sehingga apa yang dikerjakan tidak sesuai dengan yang tugas yang diberikan,

b. menemukan ide untuk paper dalam topik tertentu atau ide penelitian untuk skripsi atau tesis mereka,

c. mendapatkan sumber informasi sehingga sumber informasi kurang bervariasi dan cenderung menggunakan sumber atau format yang sama,

d. menentukan pustaka yang tepat sehingga enggan membaca karena berpikir bahwa buku-buku yang dipilih sebagai sumber informasi harus dibaca habis,

e. mengutip sebuah sumber yang berhak cipta secara langsung maupun dengan membuat parafrasa untuk menghindari plagiarisme,

f. membuat kalimat yang beralur dari paragraf ke paragraf,

g. mempresentasikan karyanya sehingga menghasilkan presentasi yang monoton, kurang informatif, dan kurang tepat untuk audiens yang dituju,

h. mempelajari hal baru dengan cara yang aktif dan kreatif.

Sementara permasalahan yang dihadapi oleh dosen dalam penulisan sebuah karya ilmiah, antara lain:

1. dosen mengajar dengan bahan yang sama dari tahun ke tahun karena kurangnya pengetahuan dalam mendapatkan bahan ajar yang bervariasi,

2. ada dosen yang sangat bergantung pada sumber di internet tanpa menguji lebih dulu sumber yang diperoleh.

Dari permasalahan yang dihadapi dosen dan mahasiswa di atas, maka dapat ditarik kesimpulan bahwa salah satu permasalahan yang dihadapi oleh perguruan tinggi yang berkaitan dengan kewajiban publikasi karya ilmiah adalah kebutuhan akan informasi yang "benar". Yang dimaksud benar di sini adalah sesuai dengan kebutuhan pemustaka dan dapat dipertanggungjawabkan sebagai sumber informasi dalam penulisan karya ilmiah.

Perpustakaan perguruan tinggi sudah seharusnya menyadari hal ini. Sebagai lembaga pendukung bagi perguruan tinggi, perpustakaan merupakan pusat penyedia informasi bagi para pemustakanya, termasuk dosen dan mahasiswa. Direktorat Jenderal Pendidikan Tinggi (2004: 3) menyebutkan fungsi perpustakaan perguruan tinggi, antara lain:

1. fungsi edukasi,

2. fungsi informasi,

3. fungsi riset,

4. fungsi rekreasi,

5. fungsi publikasi,

6. fungsi deposit, dan

7. fungsi interpretasi.

Dengan demikian, agar dapat terus eksis dan mempunyai "value of libraries" di tengahtengah situasi dunia pendidikan yang semakin kompleks akibat adanya perkembangan teknologi informasi dan komunikasi, maka perpustakaan perguruan tinggi, dalam hal ini adalah pustakawan, diharapkan menjadi "jembatan" antara sumber-sumber informasi dengan pemustaka. Kehadiran teknologi informasi dan komunikasi, khususnya internet telah membuat ledakan informasi sehingga informasi menjadi semakin tak terkendali, luas, dan tanpa batas. Hal ini secara otomatis membawa dampak positif dan negatif. Informasi 
dapat dengan mudah ditemukan dan diakses oleh siapa saja sekaligus tingkat validitas sebuah informasi menjadi samar.

Salah satu solusi yang dapat dilakukan pustakawan perpustakaan perguruan tinggi untuk mengatasi permasalahan tersebut, yakni dengan memberikan bantuan berupa layanan penelusuran sumber-sumber informasi untuk mendukung penulisan karya ilmiah bagi dosen dan mahasiswa. Agar dapat melakukan hal tersebut, tentunya pustakawan harus mempunyai skill yang memadai. Hal ini sekaligus merupakan pengembangan perpustakaan untuk memberikan layanan prima bagi pemustakanya.

Berdasarkan penjelasan permasalahan di atas, maka rumusan masalah dalam artikel ini adalah bagaimana optimalisasi layanan penelusuran sumber-sumber informasi untuk mendukung penulisan karya ilmiah dosen dan mahasiswa di perguruan tinggi.

\section{PEMBAHASAN}

Kehadiran teknologi informasi dan komunikasi, khususnya internet telah menciptakan perubahan besar dalam dunia pendidikan. Perguruan tinggi mulai berbenah menghadapi persaingan antarperguruan tinggi yang mulai ketat. Agar dapat masuk ke dalam daftar perguruan tinggi yang "berkualitas", maka penelitian/karya ilmiah yang dihasilkan oleh dosen dan mahasiswa merupakan salah satu syarat penilaian. Ditambah lagi dengan adanya surat edaran Dirjen Dikti nomor 152/E/T/012 tentang publikasi karya ilmiah yang menyebutkan, menulis karya ilmiah merupakan salah satu syarat kelulusan bagi mahasiswa jenjang sarjana, magister, dan doktor. Dalam surat keputusan tersebut, tercantum bahwa program sarjana harus menerbitkan jurnal ilmiah, program magister harus ada makalah yang terbit di jurnal ilmiah terakreditasi Dikti, sedangkan program doktor harus ada makalah yang terbit di jurnal internasional sebagai syarat kelulusan dan berhak mendapat gelar akademiknya. Dengan demikian, publikasi karya ilmiah menjadi hal yang wajib bagi dosen dan mahasiswa di lingkungan perguruan tinggi.

Agar dapat melakukan kewajiban publikasi karya ilmiah, maka informasi merupakan salah satu hal yang dibutuhkan oleh dosen dan mahasiswa. Informasi yang dibutuhkan tentu saja tidak "sembarang" jenis informasi, akan tetapi informasi yang sesuai dengan kebutuhan serta valid dan dapat dipertanggungjawabkan. Informasi yang demikian diharapkan dapat menghasilkan karya ilmiah yang baik dan berkualitas. Akan tetapi, dalam hal ini seringkali timbul permasalahan bahwa dosen dan mahasiswa kurang mengetahui dan menguasai penggunaan sumber-sumber informasi ataupun tidak mempunyai banyak waktu dalam menelusur sumber-sumber informasi yang sedemikan banyaknya.

Perpustakaan perguruan tinggi, dalam hal ini adalah pustakawan menghadapi tantangan baru di era teknologi informasi dan komunikasi. Pustakawan dituntut dapat beradaptasi dengan adanya tren yang berkembang di dunia pendidikan tinggi, termasuk di dalamnya jeli melihat permasalahan yang dihadapi oleh dosen dan mahasiswa dalam melakukan publikasi karya ilmiah. Agar dapat menjawab hal tersebut, salah satu cara yang dapat dilakukan adalah dengan menguasai kemampuan penelusuran sumber-sumber informasi menggunakan teknologi informasi dan dapat memberikan layanan tersebut kepada pemustaka.

Penelusuran informasi menurut Purwono (2008: 2) didefinisikan sebagai kegiatan menelusur kembali seluruh atau sebagian informasi yang pernah ditulis atau diterbitkan melalui sarana temu kembali informasi yang tersedia. Agar dapat melakukan penelusuran sumber-sumber informasi, pustakawan harus memiliki strategi penelusuran informasi. Strategi penelusuran informasi menurut Purwono (2008: 2) diartikan sebagai penelusuran yang dilakukan secara sistematis (systematic searching), yang 
meliputi cara-cara menggunakan kata kunci (keyword), frasa, subjek dokumen menggunakan logika Boolean (Boolean logic), serta fasilitasfasilitas penelusuran lain yang tersedia pada masing-masing search engines. Strategi-strategi yang dapat dilakukan oleh pustakawan dalam menelusur informasi secara umum adalah: (1) dengan menentukan kata kunci yang tepat dan (2) menggunakan fasilitas pencarian sumbersumber informasi.

Mengetahui atau menentukan sebuah kata kunci dari suatu topik membutuhkan "skills" karena kata kunci dianggap mewakili informasi yang dicari. Teknik pemanfaatan kata kunci atau yang disebut information scent dalam tulisan Russel-Rose \& Tate (2013) ada 3 (tiga), yakni: (1) descriptive title/judul yang mewakili informasi: bebas dari jargon dan slogan, dapat diklik, berupa kata-kata, banyak kata cenderung lebih dianggap berhasil daripada pendek. (2) Hit highlighting: kata-kata yang dianggap mewakili informasi ditandai untuk menaikkan information scent. Penanda dengan warna atau cetak tebal. (3) Clear labeling/kategori yang jelas: penggunaan kategori, cepat terbaca, sedikit tenaga.

Setelah menentukan kata kunci dalam menelusur informasi, hendaknya pustakawan juga mengetahui fasilitas pencarian sumber informasi. Menurut Surachman (2007), fasilitasfasilitas yang dapat digunakan dalam proses penelusuran informasi secara umum dibedakan menjadi dua, yakni :

1. Penelusuran informasi konvensional

Penelusuran informasi konvensional dilakukan dengan cara-cara konvensional/ manual, seperti menggunakan kartu katalog, kamus, ensiklopedi, bibliografi, indeks, dan sebagainya.

2. Penelusuran informasi digital.

Penelusuran informasi digital dilakukan melalui media digital atau elektronik seperti melalui OPAC (Online Public Access
Catalog), Search Engine (di Internet), Database Online, Jurnal Elektronik, Reference Online, dan informasi lain yang tersedia secara elektronik/digital.

Kemampuan pustakawan dalam menguasai sumber-sumber informasi menggunakan berbagai teknologi informasi sangat diperlukan dalam membantu menyediakan informasi bagi kepentingan dosen dan mahasiswa dalam publikasi karya ilmiah. Karena semakin banyaknya informasi yang beredar dan tingkat validitasnya masih diragukan, diperlukan sebuah sumber yang dapat dipercaya. Dosen dan mahasiswa sebagai pemustaka membutuhkan informasi yang valid untuk kepentingan penulisan karya ilmiahnya. Di sinilah kemampuan pustakawan seharusnya ditunjukkan secara optimal agar dapat memenuhi kebutuhan informasi bagi pemustakanya.

Kehadiran teknologi informasi dan komunikasi, khususnya internet telah menciptakan perubahan besar dalam dunia pendidikan. Kewajiban publikasi karya ilmiah bagi dosen dan mahasiswa menjadi hal yang tidak bisa dihindari. Agar dapat menghasilkan karya ilmiah yang berkualitas, dibutuhkan sumber-sumber informasi yang benar dan dapat dipertanggungjawabkan. Di sinilah perpustakaan mempunyai peran penting menjalankan fungsinya sebagai lembaga penyedia informasi. Salah satu hal yang dapat dilakukan perpustakaan dalam hal ini adalah membantu publikasi karya ilmiah bagi dosen dan mahasiswa melalui bantuan layanan penelusuran sumber-sumber informasi yang dimiliki oleh perpustakaan.

Agar dapat melakukan bantuan layanan penelusuran sumber-sumber informasi bagi para dosen dan mahasiswa, pustakawan perguruan tinggi harus mempunyai kemampuan dalam menelusur sumber-sumber informasi. Selain itu, agar dapat menemukan informasi yang sesuai dengan kebutuhan pemustaka, pustakawan harus melakukan strategi-strategi 
penelusuran informasi dengan menentukan kata kunci yang tepat dan dapat menggunakan berbagai fasilitas penelusuran informasi, baik secara konvensional menggunakan kartu katalog, kamus, ensiklopedi, bibliografi, indeks, dan sebagainya ataupun secara digital melalui OPAC (Online Public Access Catalog), Search Engine (di Internet), Database Online, Jurnal Elektronik, Reference Online, dan informasi lain yang tersedia secara elektronik/digital.

\section{PENUTUP}

Kewajiban publikasi karya ilmiah membuat perpustakaan mempunyai peran baru untuk mengembangkan layanan bantuan penelusuran sumber-sumber informasi. Sejalan dengan hukum kelima Ranganathan yang menyebutkan Library is growing organism, perpustakaan, dalam hal ini adalah pustakawan perguruan tinggi senantiasa dituntut untuk meningkatkan kemampuannya dalam memberikan layanan informasi kepada pemustaka. Pustakawan harus jeli mengetahui kebutuhan pemustakanya sekaligus melihat peluang hal-hal apa saja yang dapat dikembangkan oleh perpustakaan di masa mendatang untuk mendukung kebijakan lembaga penaungnya. Dengan kata lain, pustakawan dituntut untuk selalu kreatif dan inovatif dalam memberikan layanan yang dibutuhkan pemustaka.

Dengan hadirnya layanan yang sesuai dengan kebutuhan pemustaka, diharapkan keberadaan perpustakaan perguruan tinggi akan semakin berkembang. Karena pada hakikatnya, keberhasilan suatu perpustakaan perguruan tinggi salah satunya dapat diukur dari sejauh mana layanan yang diberikan oleh perpustakaan dapat mendukung visi dan misi lembaga utamanya, yakni universitas, sehingga semboyan library is the heart of university benar-benar dapat terwujud dengan baik

\section{DAFTAR PUSTAKA}

Direktorat Jenderal Pendidikan Tinggi. 2004. Perpustakaan Perguruan Tinggi: Buku Pedoman. Jakarta: Departemen Pendidikan Nasional RI, Direktorat Jenderal Pendidikan Tinggi.

Proboyekti, Umi. 2015. “Literasi Informasi di Perguruan Tinggi”. Diakses melalui http://lecturer. ukdw.ac.id/othie/literasiinformasiPT.pdf tanggal 1 September 2015.

Purwono. 2008. "Strategi Penelusuran Informasi melalui Internet”. Makalah, Seminar Himpunan Mahasiswa Jurusan Ilmu Perpustakaan Fakultas Adab dan Humaniora Universitas Islam Negeri Jakarta, 30 April 2008.

Ranganathan, S.R.. 1988. The five laws of library science (Sarada Ranganathan Endowment for Library Sci.

Russell-Rose, T., \& Tate, T.. 2013. Designing The Search Experience: The Information Architecture of Discovery. Amsterdam: Morgan Kaufmann.

Surachman, Arif. 2007. "Penelusuran Informasi: Sebuah Pengenalan". Materi Pelatihan Perpusdokifo, UPU Perpustakan UGM Yogyakarta.

Surat Edaran Direktorat Jenderal Pendidikan Tinggi, Kementerian Pendidikan dan Kebudayaan Nomor 152/E/T/2012 tentang Publikasi Karya Ilmiah, Kewajiban Publikasi.

Undang-Undang Republik Indonesia Nomor 43 Tahun 2007 tentang Perpustakaan 